\title{
JURAT PAJARTDONESHA
}

( Indonesian Tax Journal)

www.jurnal.stan.ac.id/index.php/JPI

\section{AUDIT DATA ANALYTICS DENGAN MS-EXCEL: USE CASE PEMERIKSAAN PAJAK}

\author{
Febrian \\ Politeknik Keuangan Negara STAN \\ Alamat Korespondensi: febrian@pknstan.ac.id
}

\section{INFORMASI ARTIKEL}

Diterima Pertama

[25062021]

Dinyatakan Diterima

[12072021]

KATA KUNCl:

Audit, , Analytics, Pemeriksaan, MS-Excel

KLASIFIKASI JEL:

H270; H110; H12O

\section{ABSTRAK}

In Tax Auditing, the main activity carried out is the proof of examining the evidence. The Examination of this evidence is done by processing data received from Taxpayers. A growing issue is data from Taxpayers that are processed not only in the form of physical form but also in the form of electronic data such as general ledger. This encourages auditors to develop Audit Data Analytics (ADA) to be able to perform a series of tests of the electronic data. At the same time, there is a tendency for auditors to use MS-Excel in almost all stages of auditing. Using design science method, this study proposes the artifact findings related to the MS-Excel model and instantiation for the implementation of ADA. The results show the framework for using MS-Excel technology artifacts in the form of steps (1) data preparation and data cleaning (2) application of data analytics (descriptive analytics, diagnostics analytics and predictive analytics).

Dalam pemeriksaan pajak, kegiatan utama yang dilaksanakan adalah pengujian bukti. Pengujian bukti ini dilakukan dengan melakukan pengolahan data yang diterima dari Wajib Pajak. Isu yang berkembang adalah data yang diolah dari Wajib Pajak tidak hanya berupa data dalam bentuk fisik, akan tetapi juga berupa data elektronik seperti pembukuan general ledger (buku besar). Hal ini mendorong pemeriksa untuk mengembangkan Audit Data Analytics (ADA) untuk dapat melakukan serangkaian pengujian dari data elektronik tersebut. Pada saat yang sama, terdapat kecenderungan pemeriksa untuk menggunakan MS-Excel dalam hampir semua tahap pemeriksaan. Penelitian ini menggunakan metode design science research mengajukan temuan artefak yang berkaitan dengan model dan instantiasi (instantiation) MS-Excel untuk implementasi ADA. Hasil penelitian didapatkan kerangka penggunaan arterfak teknologi MSExcel berupa langkah-langkah (1) data preparation dan data cleaning (2) penerapan data analytics (descriptive analytics, diagnostics analytics dan predictive analytics). 


\section{PENDAHULUAN}

Kegiatan pemeriksaan tidak lepas kaitannya dengan mengolah data yang menjadi bukti audit (Wardoyo dan Seruni 2011; Darono 2010). Hal ini sesuai dengan definisi yang tertuang dalam Pasal 1 Undang-Undang Ketentuan Umum Perpajakan (2009) (Selanjutnya disebut dengan UU KUP) yaitu Pemeriksaan adalah serangkaian kegiatan menghimpun dan mengolah data, keterangan, dan/atau bukti yang dilaksanakan secara objektif dan profesional berdasarkan suatu standar pemeriksaan untuk menguji kepatuhan pemenuhan kewajiban perpajakan dan/atau untuk tujuan lain dalam rangka melaksanakan ketentuan peraturan perundangundangan perpajakan (Presiden RI, 2007).

Data (bukti audit) yang diolah dapat berupa akuntansi, dokumentasi sistem pengendalian intern, bukti fisik, hasil perhitungan ulang, ataupun hasil prosedur analisis. Selanjutnya kemudian berkembang dengan data yang tidak hanya berbentuk fisik tetapi berbentuk elektronik. Sebagaimana disebutkan dalam Peraturan Menteri Keuangan No 17 (2013) (selanjut nya disebut PMK-17), data yang dikelola elektronik adalah data yang bentuknya elektronik, yang dihasilkan oleh komputer dan/atau pengolah data elektronik lainnya dan disimpan dalam disket, compact disk, tape backup, hard disk, atau media penyimpanan elektronik lainnya (Menteri Keuangan RI, 2013).

Untuk melakukan pengolahan data tersebut, berkembang suatu teknik yang disebut dengan Teknik Audit Berbantuan Komputer (TABK). TABK merupakan salah satu teknik yang dapat digunakan dalam pemeriksaan pajak untuk membantu pengujian data yang berbentuk elektronik. Dengan TABK, pemeriksaan pajak dapat dilakukan secara lebih efektif dan efisien. Dalam perkembangannya istilah TABK kemudian berkembang menjadi Audit Data Analytics. Istilah ini berasal dari Data Analytics yang dilaksanakan dalam bentuk pemeriksaan (audit) yang kemudian menjadi baku dengan istilah Audit Data Analytics (ADA). Singkatnya, ADA adalah teknik yang dapat digunakan untuk melakukan berbagai prosedur audit, termasuk elemen penilaian risiko, tes kontrol, substantif prosedur (yaitu, pengujian rincian atau prosedur analitik substantif), atau menyimpulkan prosedur audit (AICPA 2017; American Accounting Association 2019; 2017).

Terkait dengan perangkat yang digunakan untuk melakukan Data Analytics ini, terdapat beberapa yang dapat digunakan seperti Audit Command Language $(\mathrm{ACL})$, Interactive Data Extraction and Analysis (IDEA), Arbutus dan perangkat Generalized Audit Software (GAS) lainnya. Darono (2010) menyatakan bahwa speadsheet yaitu MS-Excel juga dapat dipertimbangkan sebagai perangkat untuk melakukan Data Analytics. Hal ini dikarenakan karena perangkat tersebut memiliki keunggulan seperti dapat melakukan fungsi-fungsi penting sebagaimana Data Analytics standar, relatif akrab-pakai serta populer di kalangan pengguna aplikasi perkantoran, relatif mudah karena para auditor biasanya sudah mempunyai dasar pengetahuan yang memadai tentang pemakaian perangkat lunak MS-Excel dan harganya relatif lebih terjangkau dibandingkan dengan perangkat $A C L$, IDEA dan perangkat GAS lainnya.

Walaupun terdapat banyak keunggulan perangkat MS-Excel dari yang lainnya, Darono (2010a) menyatakan bahwa penggunaan aplikasi MS-Excel untuk Audit Data Analytics ini memerlukan trick tertentu sehingga tujuan suatu teknik pengujian audit dapat tercapai. Hal yang menjadi menarik bagi penulis adalah bagaimanakah langkah-langkah teknis penggunaan MS-Excel jika digunakan sebagai perangkat untuk melaksanakan Data Analytics.

Untuk itu, tulisan ini dengan menggunakan perspektif design science research (lihat misalnya: Johannesson and Perjons (2014)) ingin menelaah lebih dalam bagaimana perangkat MS-Excel digunakan sebagai sebuah artefak teknologi dapat dimanfaatkan oleh auditor dalam implementasi ADA. Dengan penggunaan perspektif design science research, penelitian ini menyajikan kerangka praktikal terkait dengan artefak teknologi berupa penggunaan MSExcel yang dapat digunakan oleh auditor dalam mengimplementasikannya. Artefak dalam konteks tulisan ini adalah berupa sebuah langkah-langkah dari penggunaan MS-Excel untuk use case (lihat misalnya: (Patel, Rau-Chaplin, and Varghese (2012)) yang sesuai untuk implementasi ADA (Kogan et al., 2019; Liu, 2014). Untuk keperluan membuat artefak maka penulis akan menggunakan MS-Excel 365 yang sama halnya dengan versi MS-Excel 2019 dan MS-Excel 2016.

\section{KERANGKA TEORI}

\subsection{Pemeriksaan Pajak dan Bukti Audit Elektronik}

Menurut Mardiasmo (2013), Pemeriksaan adalah serangkaian kegiatan untuk mencari, mengumpulkan, mengolah data dan atau keterangan lainnya untuk menguji kepatuhan. Rahayu (2013) menjelaskan bahwa pemeriksaan pajak merupakan hal pengawasan pelaksanaan sistem self assesment yang dilakukan oleh wajib pajak, harus berpegang teguh pada undangundang perpajakan. Sedangkan menurut PMK-17, Pemeriksaan adalah serangkaian kegiatan menghimpun dan mengelola data, keterangan, data/atau bukti yang dilaksanakan secara objektif dan profesional berdasarkan suatu standar pemeriksaan untuk menguji kepatuhan pemenuhan kewajiban perpajakan dan/atau untuk tujuan lain dalam rangka melaksanakan ketentuan peraturan perundangundangan perpajakan (Menteri Keuangan RI, 2013).

Berdasarkan definisi di atas dapat disimpulkan bahwa pemeriksaan pajak adalah upaya yang dilakukan oleh Direktorat Jenderal Pajak (DJP) untuk melakukan pengawasan terhadap wajib pajak dengan cara menghimpun dan mengelola bukti yang ada secara profesional dan objektif terhadap kepatuhan wajib pajak dalam memenuhi ketentuan peraturan perundang-undangan perpajakan.

Pemeriksaan yang dilakukan secara objektif dan profesional adalah pemeriksaan yang dilakukan berdasarkan Standar Pemeriksaan. Menurut PER23/PJ/2013 (2013), Standar Pemeriksaan adalah 
capaian minimum yang harus dicapai dalam melaksanakan pemeriksaan. Standar Pemeriksaan meliputi Standar Umum Pemeriksaan, Standar Pelaksanaan Pemeriksaan, dan Standar Pelaporan Hasil Pemeriksaan. Standar Umum Pemeriksaan merupakan standar yang bersifat pribadi dan berkaitan dengan persyaratan Pemeriksa Pajak. Standar Pelaksanaan Pemeriksaan mengatur tata cara pelaksanaan pemeriksaan. Standar Pelaporan Hasil Pemeriksaan mengatur tentang bentuk standar laporan hasil pemeriksaan pajak (Advianto, 2014).

Salah satu standar pelaksaan pemeriksaan adalah temuan hasil pemeriksaan harus didasarkan pada bukti kompeten yang cukup dan berdasarkan ketentuan peraturan perundang-undangan perpajakan. Bukti kompeten adalah bukti yang valid dan relevan. Valid berarti bukti dapat diandalkan untuk menyimpulkan suatu fakta. Relevan berarti bahwa bukti harus berkaitan dengan pos-pos yang akan diperiksa sebagaimana telah direncanakan Rencana Pemeriksaan (audit plan) dan Program Pemeriksaan (audit program) (Direktur Jenderal Pajak 2013). Oleh karena itu bukti audit dalam pemeriksaan harus kompeten yang cukup dan sesuai dengan ketentuan peraturan perpajakan.

Salah satu bentuk bukti audit adalah bentuk data elektronik. Keberadaan bukti data elektronik untuk kepentingan audit ini menjadi semakin perlu diperdalam pembahasannya karena pada saat ini berbagai jenis catatan atas transaksi atau aktivitas organisasi tersimpan dalam perangkat teknologi informasi dan komunikasi (TIK), terutama komputer (Darono dan Febrian 2018).

Dalam praktiknya ketika melakukan pemeriksaan lapangan ke lokasi usaha/pembukuan wajib pajak, salah satu data yang wajib diperoleh oleh pemeriksa pajak adalah data pembukuan. Jika wajib pajak menggunakan sistem informasi dalam menyelenggarakan pembukuan maka data tersebut adalah general ledger (buku besar) (Direktur Jenderal Pajak, 2017). Data ini kemudian diakan dilakukan pengujian lebih lanjut untuk diuji apakah sesuai dengan ketentuan perpajakan atau tidak.

Ikatan Akuntan Indonesia dalam Standar Profesional Akuntan Publik (SPAP) SA Seksi 327 Paragraf 12 menyatakan bahwa jika suatu sistem akuntansi terkomputerisasi tidak menghasilkan bukti audit yang dapat dilihat maka tidaklah praktis bagi auditor untuk melakukan pengujian secara manual sehingga auditor harus mempertimbangkan penggunaan Teknik Audit Berbantuan Komputer (TABK) (Ikatan Akuntan Indonesia, 2001). Gray (2006) selanjutnya menyebut TABK sebagai Data Extraction and Analysis (DEA) yang selanjutnya berkembang menjadi ADA (AICPA, 2017a).

\subsection{Audit Data Analytics}

Menurut (AICPA, 2017), Data Analytics adalah “...ilmu dan seni menemukan dan menganalisis pola, mengidentifikasi anomali, dan mengekstraksi informasi berguna lainnya dalam data yang mendasari atau terkait dengan pokok bahasan audit melalui analisis, pemodelan, dan visualisasi untuk tujuan perencanaan atau pelaksanaan audit". Menurut Richardson et. al. (2019), "Data Analytics sebagai proses mengevaluasi data dengan tujuan memberikan gambaran data, Data Analytics menyediakan cara untuk mencari melalui data terstruktur dan tidak terstruktur yang besar untuk menemukan pola atau hubungan yang belum diketahui, Data Analytics sering kali melibatkan teknologi, sistem, praktik, metodologi, basis data, statistik, dan aplikasi yang digunakan untuk menganalisis beragam data bisnis untuk memberi organisasi informasi yang mereka butuhkan untuk membuat keputusan bisnis yang tepat dan tepat waktu, Data Analytics bertujuan untuk mengubah data mentah menjadi pengetahuan untuk menciptakan nilai.".

Berdasarkan definisi di atas dapat disimpulkan Data Analytics adalah proses mengevaluasi data dengan mengidentifikasi, mengekstraksi, dan mengenali pola atau menemukan berbagai anomali dari sekelompok data. Dalam kaitannya dengan pemeriksaan pajak, Data Analytics merupakan perkembangan dari TABK yang merupakan salah satu teknik pengujian dalam pemeriksaan (Direktur Jenderal Pajak, 2013). Selanjutnya istilah Data Analytics berkembang menjadi Audit Data Analytics (AICPA 2017).

Menurut Richardson et al. (2018), Data Analytics memiliki empat tingkatan yaitu:

1. Descriptive Statistics: merangkum data aktivitas atau master data berdasarkan atribut tertentu. Contoh adalah sebagai berikut

- age analysis-merangkum menurut kelompok usia

- sorting-mengurutkan dari terbesar atau terkecil

- summary statistics-merangkum nilai ratarata (mean), nilai tengah (median), nilai terkecil ( $\min )$, nilai terbesar (max), menghitung (count) dan menjumlahkan (sum)

- sampling-nilai acak (random) dan monetary unit.

2. Diagnostic: mendeteksi korelasi dan pola dari suatu data. Contoh adalah sebagai berikut

- Z-score-deteksi outlier

- Benford's law-mengidentifikasi transaksi atau pengguna dengan aktivitas tidak biasa berdasarkan distribusi digit pertama

- Drill-down-mengeksplorasi detail di balik nilai

- Exact and fuzzy matching-menggabungkan tabel dan mengidentifikasi hubungan yang tidak biasa

- Sequence check-mendeteksi celah dalam suatu ururan dan data duplikasi

- Stratification-mengelompokkan data menurut kategori

- Clustering-mengelompokkan record berdasarkan kesamaan yang belum teridentifikasi.

3. Predictive: mengidentifikasi atribut atau pola umum yang dapat digunakan untuk 
mengidentifikasi aktivitas serupa. Contoh adalah sebagai berikut

- regression-memprediksi nilai dependen spesifik berdasarkan input variabel independen

- classification-memprediksi kategori untuk sebuah record

- probability-menggunakan skor peringkat untuk mengevaluasi kekuatan klasifikasi

- sentiment analysis - mengevaluasi teks untuk sentimen positif atau negatif untuk memprediksi hasil positif atau negatif.

4. Prescriptive: merekomendasikan tindakan berdasarkan tindakan yang diamati sebelumnya. Contoh adalah sebagai berikut

- What-if analysis-sistem pendukung keputusan

- Applied statistics-memprediksi hasil atau kelas tertentu

- Artificial intelligence-menggunakan pengamatan tindakan masa lalu untuk memprediksi tindakan masa depan untuk peristiwa serupa.

Microsoft dan Pwc (2018) menyatakan bahwa data analytics telah digunakan baik yang descriptive ataupun diagnostics untuk dashboard and reporting, namun belum banyak yang menggunakannya untuk tujuan predictive atau prescriptive. Sementara itu EY (2016) menjelaskan bahwa otoritas pajak dapat menggunakan data analytics dalam skala yang luas karena jumlah dan ketersediaan data untuk pengawasan kepatuhan ataupun audit karena berbagai laporan yang diperlukan sudah berupa data elektronik. Kajian OECD (2016) menyebukan tax authority menggunakan predictive ataupun prescriptive analytics untuk berbagai area tax adminitration antara lain untuk pekerjaan audit case selection. Sejalan dengan hal tersebut, Pijnenburg et. al (2017) menyatakan bahwa otoritas pajak dapat menggunakan data analytics antara lain untuk menguji apakah pembayaran pajak yang dilakukan wajib pajak telah sesuai dengan ketentuan perpajakan.

Berdasarkan penjelasan di atas, Penulis menyimpulkan bahwa terdapat tiga tingkatan yang dapat diterapkan dalam pemeriksaan pajak yaitu, Descriptive Analytics, Diagnostic dan Predictive. Dalam bahasan berikutnya, penulis akan lebih memaparkan secara lebih dan beserta penggunaan terhadap data pembukuan general ledger untuk tiga tingkatan Data Analytics yaitu Descriptive, Diagnostic dan Predictive.

\section{METODE PENELITIAN}

Davis (2003) menyatakan design science adalah "...designing and building a new, novel artifact such as a computer application program, development methodology, or model is a contribution to knowledge ...". Sejalan dengan pengertian di atas maka pendekatan yang dipilih dalam penelitian ini adalah design science yaitu dengan mengajukan rancangan sebuah artefak teknologi dengan tujuan untuk memecahkan suatu masalah (T. H. Davenport, 2013; T.
Davenport \& Harris, 2017; Hevner et al., 2004; Zeleti et al., 2016).

Teknik pengumpulan dan analisis data yang digunakan adalah studi dokumentasi dengan analisis data kualitatif berupa kesesuaian antara teknologi yang tersedia yaitu MS-Excel dengan permasalahan yang akan diselesaikan. Penelitian ini bertujuan untuk menghasilkan artefak teknologi yang dapat digunakan untuk implementasi ADA sebagai bagian dari disiplin ilmu audit.

Selanjutnya Chatterjee \& Hevner (2010) menjelaskan langkah-langkah dalam pembentukan artefak teknologi yaitu (1) identifikasi dan deskripsi yang jelas dari problem organisasional yang relevan (2) bukti bahwa belum ada solusi yang memadai dan tambahan pengetahuan yang akan dihasilkan (3) pengembangan dan penyajian dari artefak baru (constructs, models, methods or instantiations) yang menyelesaikan masalah yang sedang dihadapi (4) evaluasi yang menyeluruh atas manfaat yang didapatkan dari artefak yang dikembangkan (5) pernyataan adanya nilai tambah terhadap praktik dan akumulasi pengetahuan dan (6) penjelasan atas implikasi terhadap praktik manajemen.

\section{HASIL PENELITIAN}

Pada bagian ini, penulis akan memaparkan bagaimana implementasi ADA dalam pemeriksaan pajak dengan membuat artefak teknologi berupa penggunaan MS-Excel. Penerapan ini dilakukan dengan mengambil contoh kasus pada pengujian data dummy general ledger (buku besar) milik wajib pajak.

\subsection{Pengembangan Artefak Teknologi}

Dalam pengembangan artefak, penulis menggunakan panduan yang diterbitkan oleh AICPA (AICPA, 2017) sebagai kerangka dasar implementasi ADA. Merujuk paragraf 2.08, panduan ADA-AICPA menjelaskan urutan langkah yang sebaiknya dilakukan oleh auditor dalam menggunakan ADA yaitu: (1) tetapkan rencana penggunaan ADA; (2) akses dan persiapan data yang akan digunakan; (3) pertimbangkan relevansi dan reliabilitas data yang digunakan; (4) laksanakan ADA; (5) evaluasi hasilnya dan mengambil kesimpulan terkait dengan tujuan dan manfaat dari pelaksanaan ADA .

Berdasarkan hal tersebut, maka posisi pengembangan artefak teknologi adalah pada langkah ke-4 laksanakan ADA. Adapun apabila pajak menghadapi data berupa general ledger (buku besar), salah satu perangkat yang dapat digunakan untuk melakukan pengujian adalah menggunakan MS-Excel yang lebih lanjut konstruksi, model, metode dan instantiasi akan dibahas pada penelitian ini.

\subsection{Audit Data Analytic dengan MS-Excel: Artefak Teknologi}

(Liu, 2014) menyatakan bahwa dalam penelitian design science, artefak teknologi dapat meliputi konstruksi, model, metode dan instantiasi. Konstruksi adalah pondasi pelaksanaan Data Analytics yang dapat dilaksanakan dalam audit menggunakan MS-Excel. 
Model yang digunakan adalah pada saat pelaksanaan ADA di langkah ke-4 ADA-AICPA. Metode yang digunakan berupa (1) data preparation dan data cleaning (2) penerapan data analytics (descriptive analytics, diagnostics analytics dan predictive analytics). Instantiasi adalah penerapan dengan menggunakan MS-Excel untuk melakukan data analytics dengan kerangka praktik ADA.

\subsection{Data Preparation dan Data Cleaning}

Johannesson dan Perjons (2014) menyatakan Instansiasi (instantiation) adalah bagian dari lingkungan yang berupa realisasi sebuah artefak secara nyata. Dalam penelitian ini, penerapan ADA dengan MS-Excel sehingga implementasi menjadi nyata adalah realisasi artefak tersebut.

Dalam penerapan ADA langkah pertama yang harus dilakukan adalah data preparation dan data cleaning. Ketika menerima data pembukuan bentuk elektronik milik Wajib Pajak, hal yang dilakukan oleh pemeriksa pajak adalah melakukan persiapan dan pembersihan data menjadi data yang siap untuk dianalisis. Hal ini diperlukan karena pada dasarnya sistem informasi yang dimiliki oleh Wajib Pajak cukup beragam. Secara umum terdapat beberapa sistem informasi yang digunakan di Indonesia, yaitu (1) Aplikasi spreadsheet seperti MS-Excel, (2) Aplikasi akuntansi tersendiri (standalone) seperti : Zahir, Accurate, MYOB dan lainnya dan (3) Sistem Informasi Enterprise atau Enterprise Resource Planning (ERP) seperti; Systems Applications and Products (SAP), Microsoft Dynamics, Axapta, Oracle dan lainnya.

Salah satu format data yang dihasilkan dari sistem informasi tersebut adalah general ledger dengan format text dengan pemisah tab delimited seperti yang terlihat pada gambar 1 .

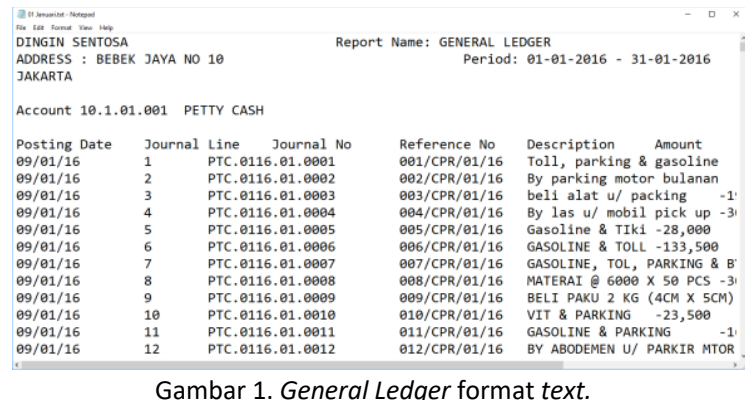

General ledger di atas tidak akan bisa dilakukan analytic apabila belum dilakukan persiapan dan pembersihan data. Proses ini dapat juga disebut dengan Extract, Transform dan Load (ETL). Menurut Richardson et al., (2018) "ETL process begins with identifying which data you need and is completed when the clean data are loaded in the appropriate format into the tool to be used for analysis". Dalam penelitian ini, penulis menggunakan MS-Excel untuk proses ETL menjadi format Excel dengan menggunakan bantuan fitur Get and Transform. Proses nya dapat dilihat pada gambar 2 .

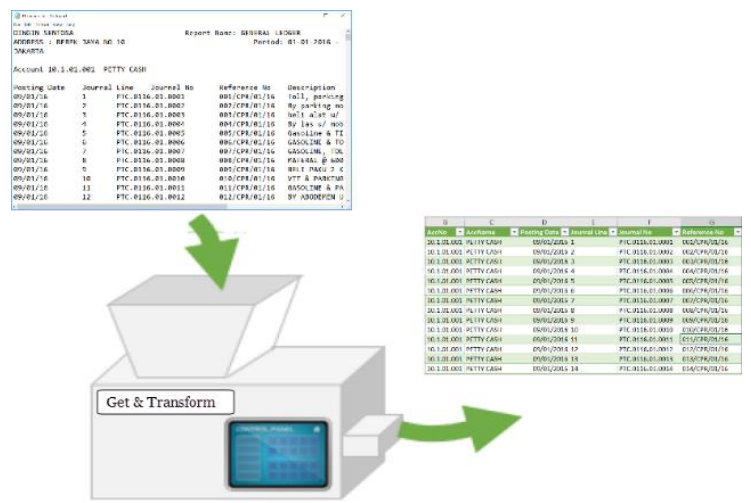

Gambar 2. Proses ETL menjadi data siap dianalisis.

Data yang siap dianalisis kemudian dibuat terlebih dahulu Trial Balance-nya (gambar 3) dengan menggunakan PivotTable MS-Excel untuk memastikan data general ledger telah valid dan lengkap. Valid dan lengkap di sini artinya telah sesuai dan cocok apabila dibandingkan dengan Trial Balance keluaran sistem.

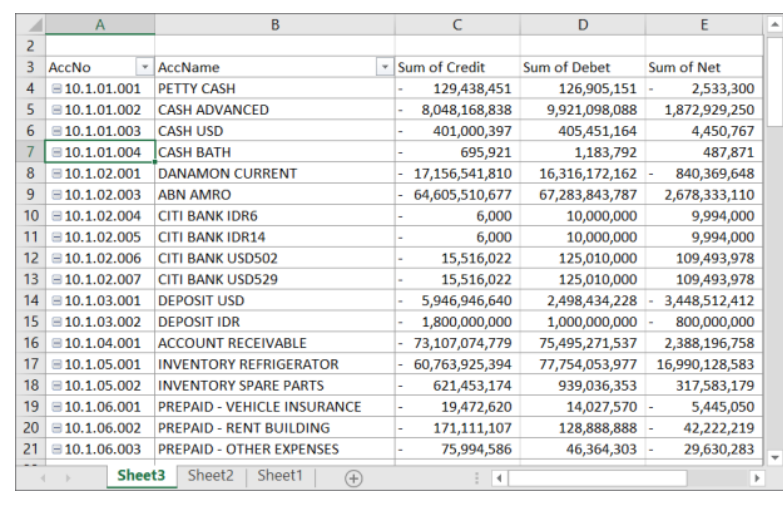

Gambar 3. Trial Balance menggunakan PivotTable.

\subsection{Penerapan Data Analytics}

Selanjutnya, setelah data preparation dan data cleaning selesai maka dilanjutkan dengan penerapan data analytics yang meliputi Descriptive Analytics, Diagnostics Analytics dan Predictive Analytics. Salah satu tujuan dari penerapan data analytics adalah kerangka praktis yang dapat digunakan untuk mendapatkan berbagai wawasan (insights) dari sekumpulan data yang dapat diakses oleh organisasi (Darono, 2020). Jika dibandingkan pemeriksa pajak harus membaca satu per satu data general ledger maka tidak menjadi praktis dalam pekerjaan audit yang banyak. Oleh karena itu data analytics menjadi suatu alat yang dibutuhkan dalam rangkaian pemeriksaan.

\section{Descriptive Analytics}

Salah satu penerapan descriptive analytics yang dapat dilakukan terhadap general ledger adalah melakukan Summary Statistics. Pada MS-Excel dilakukan dengan menggunakan PivotTable untuk menghitung Count, Summarize, Average, Min, Max seperti pada gambar 4 . 


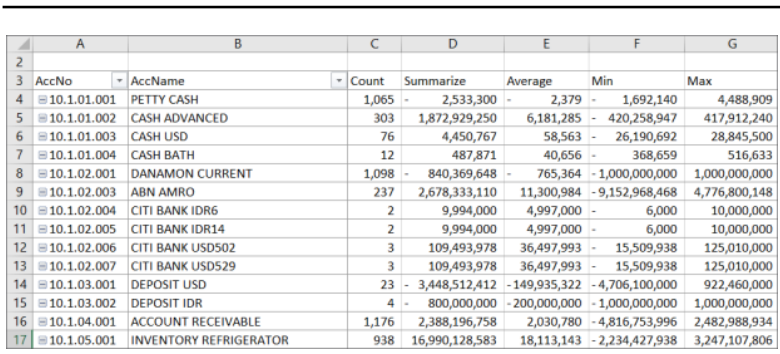

Gambar 4. Descriptive Analytics dengan Summary Statistics

Manfaat yang diperoleh dengan menggunakan summary statistics adalah dapat membuat keputusan akun-akun mana saja yang harus dilakukan lebih fokus pemeriksaan dengan menilai jumlah transaksi yang sedikit pada nilai count dan jumlah yang cukup signifikan pada summarize. Selain itu dapat pula dengan melakukan penilaian dari segi nilai Max dan Min yang memiliki rentang yang cukup jauh. Sebagai contoh penggunaan summary statistics, dari Gambar 4 dapat diketahui bahwa rekening yang sering digunakan adalah pada akun ABN AMRO dari hasil count dan summarize yang paling besar dari akun rekening lainnya sehingga fokus pemeriksaan terhadap rekening dapat dilakukan pada akun tersebut. Kekurangan dari penggunaan PivotTable MS-Excel untuk melakukan summary statistics adalah tidak bisa membuat nilai Median. Nilai Median sendiri diperlukan untuk melihat nilai yang berada ditengah-tengah antara Min dan Max.

\section{Diagnostic Analytics}

Penerapan diagnostic analytics yang dapat dilakukan terhadap general ledger salah satunya adalah melakukan Drill-down pada PivotTable dengan cara mengklik ganda pada bagian Value dari PivotTable dalam hal ini contohnya nilai Net akun yang ingin dipelajari lebih lanjut. PivotTable yang diklik adalah hasil dari pembuatan summary statistics sebelumnya. Misalkan pemeriksa pajak ingin mempelajari akun Sales Refrigator maka cara melakukan Drill-down adalah seperti pada gambar 5.

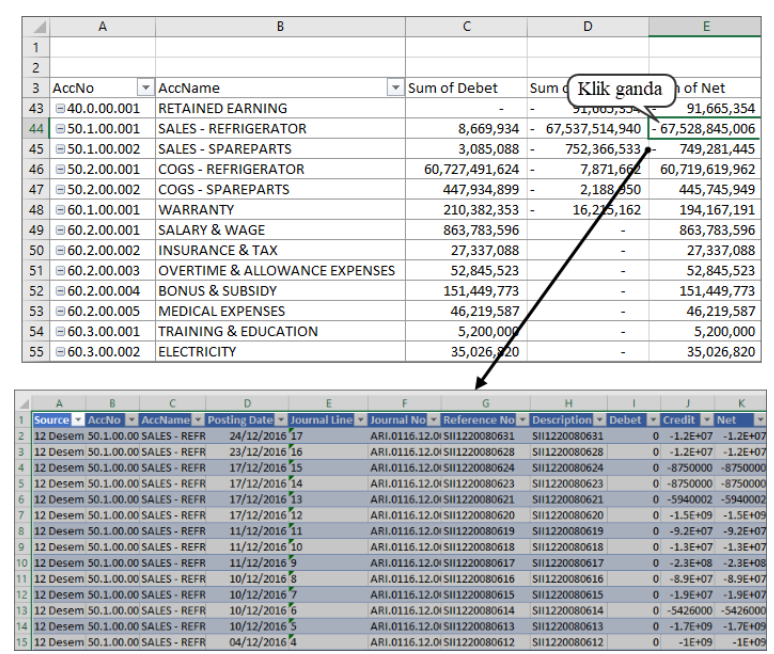

Gambar 5. Drill-down.
Manfaat yang diperoleh dengan menggunakan Drill-down adalah kemudahan dalam melihat akun demi akun yang ingin dipelajari lebih lanjut hanya dari satu sumber PivotTable dan cukup diklik ganda. Hal ini juga membuat data general ledger terorganisir dengan baik karena sumber utama analisis adalah Trial Balance dari PivotTable.

\section{Predictive Analytics}

Penerapan predictive analytics yang dapat dilakukan terhadap general ledger adalah Sentiment Analysis yaitu dengan melakukan penilaian terhadap setiap transaksi pada general ledger apakah terindikasi ada kewajiban pajak yang muncul dari pengunaan kata-kata pada kolom Account Name (nama akun) dan Description (keterangan). Katakata yang digunakan harus disusun sebelumnya. Berikut adalah contoh beberapa kata-kata dan indikasi kewajiban pajak yang muncul di setiap penggunaannya yang dapat dilihat pada tabel 1 .

Tabel 1. Kata-kata dan indikasi perpajakan

\begin{tabular}{|l|l|}
\hline KATA-KATA & JENIS PAJAK \\
\hline SALES & PPN \\
JUAL & PPN \\
DONASI & Non Deductible \\
SUMBANGAN & Non Deductible \\
COMMUNICATION & Non Deductible \\
MEDICAL & Non Deductible \\
SEWA BANGUNAN & PPh 4(2) \\
ROYALTI & PPh 26 \\
MAINTENANCE & PPh 23 \\
SALARY & PPh 21 \\
PELAYARAN & PPh 15 \\
\hline
\end{tabular}

Untuk mengaplikasikan Sentiment Analysis, pemeriksa pajak dapat membuat function pada Get and Transform. Function adalah semacam script yang dapat dijalankan secara berulang. Dalam hal ini script digunakan untuk menjalankan perintah untuk mencari kata-kata yang sudah dibuat ke setiap baris pada setiap transaksi dan apabila diketemukan maka buat kolom baru berupa jenis pajak terkait. Prinsip kerja Sentiment Analysis menggunakan function pada Get and Transform dapat dilihat pada gambar 6 .

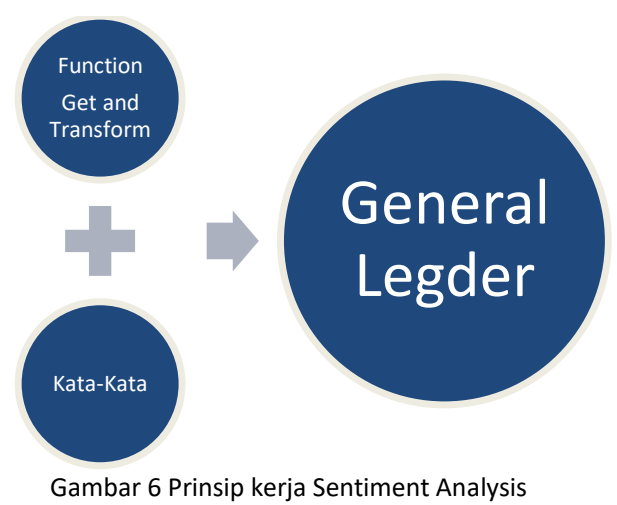

Hasil dari penerapan Sentiment Analysis dapat dilihat pada gambar 7 . 


\begin{tabular}{|c|c|c|c|c|c|c|}
\hline$\triangle$ & B & c & & $\mathrm{H}$ & & \\
\hline 1 & Account $-\square$ & AccountName & 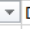 & Description & $\checkmark$ & Find.TaxId \\
\hline 607 & 50.1 .00 .001 & SALES - REFRIGERATOR & & SII0120080001 & & PPN \\
\hline 608 & 50.1 .00 .001 & SALES - REFRIGERATOR & & SII0120080002 & & PPN \\
\hline 609 & 50.1.00.001 & SALES - REFRIGERATOR & & S110120080003 & & PPN \\
\hline 610 & 50.1.00.001 & SALES - REFRIGERATOR & & S110120080004 & & PPN \\
\hline 611 & 50.1 .00 .001 & SALES - REFRIGERATOR & & SII0120080005 & & PPN \\
\hline 612 & 50.1 .00 .001 & SALES - REFRIGERATOR & & SII0120080006 & & PPN \\
\hline 613 & 50.1 .00 .001 & SALES - REFRIGERATOR & & S110120080007 & & PPN \\
\hline 614 & 50.1.00.001 & SALES - REFRIGERATOR & & S110120080008 & & PPN \\
\hline 615 & 50.1 .00 .001 & SALES - REFRIGERATOR & & SII0120080009 & & PPN \\
\hline 616 & 50.1 .00 .002 & SALES - SPAREPARTS & & SIII0120080010 & & PPN \\
\hline 617 & 50.1 .00 .002 & SALES - SPAREPARTS & & SII0120080011 & & PPN \\
\hline 618 & 50.1 .00 .002 & SALES - SPAREPARTS & & SII0120080012 & & PPN \\
\hline 619 & 50.1 .00 .002 & SALES - SPAREPARTS & & SII0120080013 & & PPN \\
\hline 620 & 50.1.00.002 & SALES - SPAREPARTS & & SII0120080014 & & PPN \\
\hline 621 & 50.1.00.002 & SALES - SPAREPARTS & & SII0120080015 & & PPN \\
\hline
\end{tabular}

Gambar 7. Hasil Sentiment Analysis

Manfaat yang diperoleh dengan menggunakan Sentiment Analysis adalah dapat mencari koreksi pemeriksaan dengan cepat dan dapat diaplikasi ke pemeriksaan berikutnya karena pada prinsipnya pemeriksaan adalah menguji pembukuan wajib pajak dalam hal ini general ledger. Kata-kata yang telah dibuat dapat dikumpulkan hingga menjadi perbendaharaan kata yang dapat digunakan dan disebarluaskan sehingga dapat dimanfaatkan oleh pemeriksa-pemeriksa di lingkungan DJP.

\section{KESIMPULAN DAN SARAN}

Penggunaan MS-Excel merupakan salah satu alternatif teknik pengolahan data yang dapat digunakan dalam pemeriksaan untuk mengimplementasikan ADA yang dalam masa yang akan datang semakin banyak menghadapi bukti audit berupa pembukuan secara elektronik dengan ukuran semakin besar. Hasil dari penggunaan artefak teknologi berupa langkah-langkah (1) data preparation dan data cleaning (2) penerapan data analytics (descriptive analytics, diagnostics analytics dan predictive analytics) berupa data yang dapat dioleh lebih lanjut sehingga dapat menghasilkan temuan audit yang berkualitas.

Penelitian ini mempunyai keterbatasan yaitu hanya menggunakan tiga jenis data analytics (satu dari setiap jenis) dan perlu dikembangkan lagi untuk dapat dilakukan pada jenis data analytics lainnya. Saran penulis adalah perlu adanya pengaplikasian Prescriptive Analytics dalam pemeriksaan pajak dalam bentuk Artificial Intelligence atau Machine Learning sebagai pelengkap tingkatan Data Analytics yang saling keterkaitan satu sama lain pada DJP.

Artefak yang telah dikembangkan dalam penelitian ini perlu diterapkan pada pemeriksaan pajak sebenarnya agar didapatkan kesimpulan sesuai dengan kebutuhan pemeriksa pajak. Selain itu, hasil penelitian ini diharapkan menjadi referensi untuk penggunaan metode design science research yang belum terlalu banyak diaplikasikan di Indonesia.

\section{DAFTAR PUSTAKA (REFERENCES)}

Advianto. (2014). Bukti Audit Kompeten Dalam Pemeriksaan Pajak dan Pembuktian Dalam Sengketa Pajak. https://bppk.kemenkeu.go.id/content/berita /pusdiklat-pajak-bukti-audit-kompetendalam-pemeriksaan-pajak-dan-pembuktiandalam-sengketa-pajak-2019-11-05157cde20/

AICPA. (2017a). Guide to Audit Data Analytics. American Institute of Certified Public Accountants, Inc.

AICPA. (2017b). Guide to Audit Data Analytics. American Institute of Certified Public Accountants, Inc.

American Accounting Association. (2017). Accounting IS Big Data 2017. https://aaahq.org/Meetings/2017/Accounting -Is-Big-Data-Conference

American Accounting Association. (2019). Intensive Data and Analytics. https://aaahq.org/Meetings/2019/SummerW orkshop2019

Chatterjee, S., \& Hevner, A. R. (2010). Design research in information systems: Theory and practice. Springer.

Darono, A. (2010a). Penerapan Data Extraction and Analysis/generalized Audit Software Berbasis Aplikasi Spreadsheet. Seminar Nasional Aplikasi Teknologi Informasi (SNATI).

Darono, A. (2010b). Teknik Audit Berbantuan Komputer: Menelaah Kembali Kedudukan dan Perannya. Seminar Sistem Informasi Indonesia.

Darono, A. (2020). Web Data Extraction Dalam Analitika Data Audit: Pengembangan Artefak Teknologi Dalam Perspektif Design Science Research. Teknika, 9(2), 97-105.

Darono, A. \& Febrian. (2018). Power Query untuk Auditor. Elex Media Komputindo.

Davenport, T. H. (2013). What do we talk about when we talk about analytics? Enterprise Analytics, Optimize Performance, Process and Decision through Big Data, 9-18.

Davenport, T., \& Harris, J. (2017). Competing on analytics: Updated, with a new introduction: The new science of winning. Harvard Business Press.

Davis, G. B. (2003). Building an international academic discipline in Information Systems. Exploring Patterns in Information Management: Concepts and Perspectives for Understanding IT-Related Change.

Direktur Jenderal Pajak. (2013a). PER-23/PJ/2013 Tentang Standar Pemeriksaan. Direktorat Jenderal Pajak.

Direktur Jenderal Pajak. (2013b). SE-65/PJ./2013 tentang Penggunaan Metode dan Teknik Pemeriksaan. Direktorat Jenderal Pajak.

Direktur Jenderal Pajak. (2017). SE-10/PJ/2017 Tentang Petunjuk Teknis Pemeriksaan Lapangan Dalam Rangka Pemeriksaan Untuk Menguji Kepatuhan Pemenuhan Kewajiban Perpajakan. Direktorat Jenderal Pajak.

EY. (2016). Tax Administration Is Going Digital: Understanding the Challenges and Opportunities. EY Center for Tax Policy. Ernst \& Young LLP. 
Gray, G. L. (2006). "An Array of Technology Tools". Internal Auditor.

Hevner, A. R., March, S. T., Park, J., \& Ram, S. (2004). Design science in information systems research. MIS Quarterly, 75-105.

Ikatan Akuntan Indonesia. (2001). Standar Profesional Akuntan Publik (SPAP) SA Seksi 327 Paragraf 12.

Johannesson, P., \& Perjons, E. (2014). An introduction to design science. Springer.

Kogan, A., Mayhew, B. W., \& Vasarhelyi, M. A. (2019). Audit data analytics research-An application of design science methodology. Accounting Horizons, 33(3), 69-73.

Liu, Q. (2014). The application of exploratory data analysis in auditing.

Mardiasmo. (2013). Perpajakan Edisi Revisi 2013. CV Andi Offset.

Menteri Keuangan RI. (2013). PMK-17/PMK.03/2013 tentang Tata Cara Pemeriksaan. Kementerian Keuangan RI.

Microsoft \& Pwc. (2018). The Data Intelligent Tax Administration-Meeting the Challenges of Big Tax Data and Analytics. Netherland: Microsoft and PricewaterhouseCoopers Belastingadviseurs N.V.

OECD. (2016). Advanced Analytics for Better Tax Administration Putting Data to Work. https://read.oecd-

ilibrary.org/taxation/advanced-analytics-forbetter-tax-administration_9789264256453en\#page1

Patel, I., Rau-Chaplin, A., \& Varghese, B. (2012). A platform for parallel $R$-based analytics on cloud infrastructure. 188-193.

Pijnenburg, M., Kowalczyk, W., \& Van Der, H. D. L. (2017). A Roadmap for Analytics in Taxpayer Supervision. The Electronic Journal of EGovernment 15 (1): 19-32.

Presiden RI. (2007). Undang-Undang Nomor 28 Tahun 2007 tentang Ketentuan Umum Perpajakan.

Rahayu, S. K. (2013). Perpajakan Indonesia: Konsep \& Aspek Formal. Kencana Prenada Media Group.

Richardson, Venon J., Teeter, R. A., \& Terrell, K. L. (2018). Data Analytics fo Accounting. Mc Graw Hill Education.

Richardson, V.J., Teeter, R. A., \& Terrell, K. L. (2019). Data Analytics for Accounting. McGraw-Hill Education. https://books.google.co.id/books?id=Sh6ptQE ACAAJ

Wardoyo, T. S., \& Seruni, P. A. (2011). Pengaruh Pengalaman dan Pertimbangan Profesional Auditor Terhadap Kualitas Bahan Bukti Audit yang Dikumpulkan (Studi Kasus Pada Kantor Akuntansi Publik di Bandung). Akurat Jurnal Ilmiah Akuntansi, 2(06).

Zeleti, F. A., Ojo, A., \& Curry, E. (2016). Exploring the economic value of open government data. Government Information Quarterly, 33(3), 535-551. 